\title{
PERSOONWEES EN DIE MORELE STATUS VAN DIE MENSLIKE EMBRIO
}

\author{
Kobus Smit \\ Departement Filosofie \\ Universiteit van die Oranje-Vrystaat \\ BLOEMFONTEIN
}

\begin{abstract}
During the last decades the moral status of the human embryo has been compromised in numerous ways. A survey of these reveals the consistent influence of the ideology of the freedom of the human person. Screening the criteria for assigning moral status (if at all) to the human embryo, 'personhood' is the main consideration. In this article the relevance of this criterion is examined from a Christian perspective on man and his ethical life. The conclusion is that the old Scholastic dualism of body and soul has been traded in for a dichotomy of person and body. Personhood is then defined in purely humanistic terms as qualified by rationality, self-conscious decisions, et cetera. An integral view of man becomes impossible and man's bodily existence is devalued. Ethically the results are devastating. The paradigm for treating the ethical issues in this regard should be far more comprehensive and extensive, as only the Christian world view can guarantee.
\end{abstract}

\section{MEDIES-TEGNIESE LEWENSONTLUISTERING}

Die probleem van die bedreigde morele status van die menslike embrio is bestem om aktueel te bly. Dit is 'n tema wat verskeie probleemgebiede van die mediese etiek raak, en gaan veral oor sekere vorme van infertiliteitsbehandeling, aborsie, navorsing op embrio's en die gebruik van fetale weefsel vir terapeutiese doeleindes.

Die verbetering in die kwaliteit van lewe wat deur die mediese tegnologie in die afgelope dekades moontlik gemaak is, kan nie grondig genoeg waardeer word nie. Daagliks word die ellende van siekte, pyn en dood teruggedu deur nuwe medies-tegniese ontdekkings. Die vreugde wat mediese navorsing gebring het deur moderne fertiliteitsbehandeling, is een van die mooiste hoofstukke in sy geskiedenis. Die nood van kinderloosheid is 'n eksistensiële nood en ouerskap een van die rykste vreugdes.

Die mediese wetenskap het egter ook 'n ander kant. Dit bevorder nie net lewe nie, maar bedreig ook lewe ... ongebore menslike lewe. Terwyl dit vanselfsprekend is dat mediese navorsing ingestel is op die verligting van nood en dat mediese navorsingspanne meesal bewus is van die morele implikasies van hulle werk, maak die medies- 
tegniese lewensontluistering tog 'n dissipline soos mediese etiek noodsaaklik. Die versoeking in die wetenskap om die diensmotief te verruil vir die magsmotief is ook op hierdie terrein aan die orde van die dag.

In hierdie artikel word die morele status van die menslike embrio eers geweeg in die lig van beskikbare gegewens. Daarna word die kriteria wat aangelê word vir die toekenning of ontsegging van morele status, ondersoek. Omdat persoonwees in die moderne debat die sentrale kriterium is, word dit vervolgens ondersoek. Die beoordeling van die probleem word gedoen vanuit 'n Christelik-wysgerige antropologie en etiek (wat as bekend veronderstel word).

Niemand spring die netwerk van makro- en mikro-ideologieë van die moderne Westerse maatskappy vry nie. Die ideologie van natuurwetenskaplike beheersing van die werklikheid het as polêre teëhanger die ideologie van die veiligstelling van die vryheid van die outonome indiwiduele persoon. Sentrale idees van hierdie ideologie in die huidige debat soos persoonwees, beheersingsmag, die morele aard, rasionaliteit en outonomie van die indiwidu en die reg op privaatheid, sal ter sprake wees.

Andersyds val die klem op die afwesigheid en ontoelaatbaarheid in die moderne debat van idees soos openbaring, skeppingsordeninge, persoonwees as beeld-van-God-wees, normatiewe strukture vir die huwelik en gesin en transendente verantwoording.

\section{BEDREIGDE MORELE STATUS}

Watter aanduidings bestaan daar dat die morele status van die menslike embrio bedreig word? In die paradigma van die moderne debat oor genetiese manipulasie word 'n mens se morele status veral gemeet aan sy rasioneel-gekoppelde vermoëns wat eers 'n ruk na geboorte begin gestalte kry, ontwikkel tot 'n hoogtepunt en verdwyn wanneer breinskade plaasvind of seniliteit intree.

* Die erodering van die morele status van die menslike embri i blyk uit die terme (metafore) waarmee na ongebore menslike lewe verwys word. In die mediesetiese literatuur kom terme voor soos biologiese larwe, pre-embrio, 'n massa afhanklike protoplasma, 'n gewas of swelsel, 'n biotiese entiteit met 'n morele status vergelykbaar met dié van 'n paddavis, 'n pasgebore guppy, 'n rot, 'n slaaikop of 'enige ander soort groente'.

* Die pertinentste aanduiding van die verlies aan morele status is die wetgewing in Westerse en Oosbloklande. Die abortuswetgewing in hierdie lande reflekteer omtrent geen morele status vir die embrio voor die wet nie. Die regstatus van die 
menslike embrio korreleer uiteraard met die morele status. (Ironies genoeg is dit oorwegend Latyns-Amerikaanse en Afrika-lande wat nog wetgewing teen abortus het.)

Die Amerikaanse Appélhof se uitspraak in die saak Roe vs Wade (1973) het 'n geweldige invloed gehad (Leiser, 1981:33/47). Dit was 'n groot oorwinning vir die pro choice-faksie wat veg vir vrye aborsie. Sedert 1989 het die gety effens gekeer en doen die Amerikaanse Appélhof uitsprake wat die hoop vir die pro life-faksie, wat veg vir die morele status van die menslike embrio, weer laat opvlam het (Time, 1989a:38/40; 1989d:66/7). Die uitspraak in Roe vs Wade sentreer om twee bevindings:

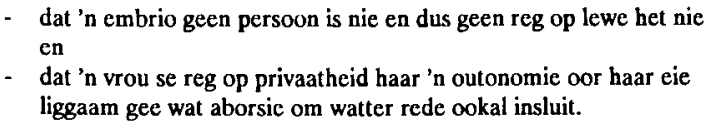

Hierdie twee argumente het oorheersende status in die Weste.

* Die ander aanduider van hoe ver dit heen is, is statistieke (vgl. Du Toit, 1978:21/33; Häring, 1982:150). Tussen 1949 en 1967 is 16395616 aborsies in Japan geregistreer. Volgens 'n berig in Time (1989c:50-53) blyk dit dat die aantal aborsies per jaar per 1000 vroue tussen 15 en 44 jaar wissel van 5.6 in Nederland tot 181 in Rusland. Die orde is Nederland, Wes-Duitsland, Kanada, Brittanje, Frankryk, Australië, Pole, Italië, Israel, die VSA, China, Roemenië en Rusland.

Die totale aantal aborsies per jaar word bereken op enigiets van 30 tot 60 miljoen.

* Die verlies van die morele status van die embrio korreleer ironies genoeg met die toename in medies-tegniese mag. Die morele aanvaarding van medies-tegniese prosedures lei tot praktyke wat moreel bevraagteken kan word. Die argument van die dun-end-van-die-wig is nie sonder grond nie:

Kunsmatige inseminasie met saad van die eggenoot (KIE) het gelei tot kunsmatige inseminasie met saad van 'n donateur (KID); in vitro-bevrugting (IVB) met gamete van 'n getroude paar het gelei tot IVB met gamete deur skenkers van buite die huwelik; IVB hang weer saam met embrio-oordrag (EO) en lei tot surrogaatmoederskap.

Nuwe tegnieke in ooreenstemming met hierdie medies-tegniese vordering is selektiewe doding van fetusse in die geval van 'n veelvoudige swangerskap en die gebruik van aborsie ter wille van geslagseleksie (vgl. Dunstan, 1986:34/8). 
* Talle navorsingsprojekte wat tans aan die gang is, word gedoen met embrio's. Die ontwikkeling van die in vitro-bevrugting-tegniek het die meeste van hierdie projekte moontlik gemaak. In die meeste gevalle is die eventuele doodmaak of laat doodgaan van embrio's deel van die navorsing.

In 'n ontleding van sulke projekte gee Mary Sellers en Elliot Phillipp (in Dunstan 1986:22/31) die volgende voorbeelde:

- Navorsing om die kulture waarin embrio's gehanteer word, te verbeter; genetiese siftingsprogramme om kongenitale afwykings te spoor, die embrio te klief, een deel te vries en die ander te ontwikkel en te toets vir chromosomale afwykings; navorsing om onnodige spontane aborsie te voorkom, om die aborsiepil te verbeter ter wille van groter veiligheid vir die moeder; terapeutiese navorsing met fetale breinseloorplantings en bynieroorplantings en die gebruik van fetale weefsel in navorsing op die terrein van virologie en kankerterapie.

- Naas Parkinsonisme, diabetes en ander siektes word ook gekyk na die moontlikheid om breinstamselle van die embrio te gebruik in die geval van miokardiale infarksie omdat hulle die vermoë het om op inwerking van die omgewing te kan differensieer in verskillende soorte selle. Dit word voorsien dat leukemie ook met breinselle in plaas van beenmurg behandel sal kan word.

By die internasionale kongres oor Philosophical Ethics and Reproductive Medicine te Leeds in 1988 is oor 'n navorsingsprojek by die fertiliteitskliniek van die Vrije Universiteit van Brussel verslag gedoen. Hierdie fertiliteitskliniek bedien ongetroude dames en lesbiese pare. Tot Maart 1988 het hulle 27 uit 34 lesbiese pare aanvaar vir behandeling. Ongeveer 17 kinders was reeds op daardie stadium gebore waarvan die oudste 6 was. Volgens die navorsers is daar geen bewys dat kinders van lesbiese pare abnormaal sal ontwikkel nie. Kinders kan identifikasiefigure van buite die 'gesin' kies. Die beoordeling van hulle navorsing hang saam met die beoordeling van homoseksualiteit deur die gemeenskap en dit het drasties verander. Die kliniek sal die kinders se ontwikkeling monitor en bepaal wat die invloed op hul persoonlikheidsontwikkeling is (Dalton, 1988:15). Dat die embrio in hierdie geval die vereiste morele raamwerk vir optimale persooonlikheidsgroei verbeur, is nie 'n oorweging nie.

- Ook Suid-Afrika worstel met 'n kampanje vir die liberalisering van die aborsiewet. Die Departement Nasionale Gesondheid en Bevolkingsontwikkeling het menings ingewin (tot en met einde Augustus 1990) oor die moontlike hervorming van die aborsiewet (Eastern Province Herald, 1990:5). Die afgelope tyd is talle kongresse oor die saak gehou. Op een hiervan pleit Dot Cleminshaw (The Cape Times, 
1990:6) vir die liberalisering van die wet onder die vaandel van vroueregte en die outonomie van die moeder: "All we are asking for is that abortion should be a private matter between a woman and her doctor." Sy maak gebruik van statistiek: 100000 onwettige aborsies vind per jaar plaas. Andersyds word gewys op die posisie van die ongewensde kind.

Op 'n kongres in Kaapstad pleit dr. Majorie Dyer (Die Volksblad, 1990:5) ook vir liberalisering: "Die vrou is die enigste een wat namens die fetus kan praat." Die kerk moet aanvaar dat dit die reg van die vrou is om 'haar gesin' te beplan 'soos en wanneer sy wil'. Volgens haar het navorsing bowendien aangedui dat geen bevolkings-beperkingsprogram kan werk sonder om van wettige aborsies gebruik te maak nie. Die kerk word opgeroep om mee te werk om die aborsiewet 'mensliker' te maak. Die betekenis van 'mensliker' en van 'gesin' in hierdie verband is 'n kwessie van perspektief. Die argumente is altyd dieselfde: die reg op privaatheid ("a private matter between a woman and a doctor") en die outonomie van die vrou ("soos en wanneer sy wil").

Die resultaat van die meningsopname was dat $98,62 \%$ van die 48846 mense wat gereageer het, teen enige wysiging van die Wet op Aborsie en Sterilisasie was en dat geen wysiging dus deur die betrokke minister oorweeg word nie (Cape Times, 1991:5).

\section{KRITERIA VIR DIE BEPALING VAN DIE MORELE STATUS VAN DIE MENSLIKE EMBRIO}

'n Oorsig oor die debat oor die morele status van die menslike embrio bevestig dat verskeie stadia van embrionale ontwikkeling geneem word as kriteria vir die bepaling van wanneer die morele status begin. Dit blyk dat die stadia van ontwikkeling hoe later hoe meer ontaard het in stasies van statusloosheid. In hierdie paragraaf word ingegaan op die onderskeie moontlikhede of 'afkappunte' met die doel om te bepaal of die keuses arbitrêr is of nie.

Om dit te staaf, word veral van twee oorwegings gebruik gemaak:

- die finaliteit van die genetiese kode by bevrugting en

- die dodelike kontinuiteit van die ontwikkeling van die ongebore mens. 


\subsection{Bevrugting}

Soos aangedui, word 'n pro choice-standpunt geassosieer met die indiwidualistiesliberalistiese tradisie waar die outonomie van die moeder deurslaggewend is en die vader omtrent geen rol speel nie. Bevrugting is geen oorweging werd as dit kom by die morele status van die embrio nie.

Pro life dra die etiket van absolutisties, dogmaties en ultra-konserwatief. Dit gaan uit van die oomblik van bevrugting as die begin van menslike lewe in die volle betekenis daarvan.

Enkele standpunte in die pro choice/ pro life-debat word vervolgens aan die orde gestel.

* Die Anglikaanse teoloog G.R. Dunstan verwerp (op bogenoemde kongres te Leeds) die pro life-standpunt as 'absolutisties' omdat lewe volgens 'die bioloë' nie begin by bevrugting nie. Vir hom is daar tot op 14/15 dae, voordat orgaandifferensiëring begin, geen sprake van identiteit/indiwidualiteit/uniekheid nie en daarom is 'n embrio nie geregtig op dieselfde morele status as 'n menslike persoon nie. Vra hy na wanneer identiteit begin, weerspreek hy homself. Die moontlikheid van identiteit (hyself beklemtoon moontlikheid!) is volgens hom neergelê vroeg in die vorming van die gamete in die onderskeie liggame van die ouers. Die moontlikheid word werklikheid nié in 'n oomblik nie, maar in die verloop van 'n proses.

The union of sperm and ovum to form the zygote does not create a new unique individual, it carries forward a process already begun. (Dunstan, 1988:13).

* Dieselfde standpunt word ook verwoord deur die Etiese Komitee van die Amerikaanse Fertiliteitsvereniging in reaksie op die Rooms-Katolieke beleidsverklaring (1987) in hierdie verband.

$$
\begin{aligned}
& \text {... it remains fundamentally inconsistent to assign the status of human individual to the human } \\
& \text { zygote or early pre-embryo when compelling biological evidence demonstrates that individuation, } \\
& \text { even in a primitive biological sense, is not yet established (Kempers, 1988:3S). }
\end{aligned}
$$

Op dieselfde bladsy word aangedring op 'n rasionele basis vir die bespreking en word die oorweging van openbaringsgegewens prinsipieel uitgesluit. Daar word verwys na die probleem van algemene norme in 'n lewensbeskoulik-pluralistiese samelewing (Kempers, 1988:7S).

- Die Nederlandse psigiater H. Blijham (humanis van oortuiging) maak beswaar teen die idee dat bevrugting 'n proses sou wees en dat daar 'n 'voor-menslike' 
bestaan na bevrugting moontlik sou wees. Hy lê klem op die 'vrug' in 'bevrugting'; dit gaan nie oor 'n 'vrugbeginsel' nie.

Daar bestaan 46 chromosome vanaf bevrugting.

Dit alles betckent zonder enig spoor van twijfel dat er met de bevruchting een complest, geïdentificeerd, chromosomaal gecodeerd, individueel en persoonlijk menselijk leven een aanvang heeft genomen ... (Blijham, 1984:77).

Alles wat die mens uiteindelik as persoon kan realiseer, is in beginsel reeds teenwoordig in die bevrugte eisel. Ontwikkeling is altyd kontinu. In die menslike curriculum, gereken van konsepsie tot by die dood, is daar geen steekhoudende rede waarom 'n mens 'n grens sou aanbring waarna 'n mens vir die eerste keer van menslike lewe (en dus morele status) sou kon praat nie.

'n Embrio is beslis ook geen bloudruk van 'n mens nie want by bevrugting ontstaan 'n waardevolle, unieke menslike lewe met persoonlike herkenbaarheid (Blijham, 1984:77/8).

Hiermee hang saam die vermoë tot waarneming, geheue, reproduksie, kodering, doelmatigheid, relasionele betrokkenheid op die omgewing, ensovoorts.

* Volgens John Noonan beskou die kontinuïteitsidee bevrugting tereg as die begin van menslike lewe. Wanneer die genetiese kode met bevrugting bepaal is, is die res van die ontwikkeling 'n kontinue voortsetting van wat reeds teenwoordig is. Hierdie genetiese informasie bepaal die mens se eienskappe, onder andere die moontlikheid van menslike wysheid. "A being with a human genetic code is man" (Noonan, 1977:16).

* Ook vir Daniel Callahan besit die embrio 'n uniekheid ("its own distinctive and individual future") wat verskil van sperm en ovum en wat kontrasepsie en aborsie eties totaal verskillend maak. Die teorie dat 'n embrio blote 'weefsel' is, kan alleen geloofwaardig gemaak word deur die biologiese feite sistematies te negeer. 'n Embrio groei deur sy eie biologiese dinamiek. Dit het genetiese en morfologiese potensiaal wat van die moeder s'n verskil het en 'n onderskeie en indiwiduele toekoms (Callahan, 1977:27, 29).

Hy beskou die embrio egter bloot as potensiële menslike lewe. Aborsie is dus nie die vernietiging van 'n menslike persoon nie, omdat die vrug nie beantwoord aan die definisie van 'n persoon nie. (Hy noem vermoëns soos om te kan redeneer, wil, begeer en relateer.) Aborsie is vir hom definitief 'n daad van doding. "That fact should not be disguised, or glossed over by euphemism and circumlocution" 
(Callahan, 1977:29).

* Vir Helga Kuhse (1982:31) is die lewe van die ongebore mens vanaf konsepsie tot en met geboorte eties neutraal. Saam met Peter Singer (1982:33) verwys sy na idiologiese teenstanders se aksent op die genetiese uniekheid van die menslike embrio as spesiesisme. In hul beredenering kan hulle geen verskil sien in die morele status tussen sperm en ovum apart en verenig as sigoot nie en is die embrio nie vanaf bevrugting ten volle mens nie. Volgens hul siening is die meeste wat ' $n$ mens kan sê dat die embrio lid is van die spesie homo sapiens maar nie dat dit 'n reg op lewe het nie. Kuhse en Singer (1982:60) beweer dat spesie nie die grond van regte is nie!

Die redenasie veronderstel 'n ewolusionistiese antropologie waarin die register van vergelykbares gereduseer word en die mens hoogstens 'n besondere soogdier is. (Oor die unieke aard van menswees vergelyk Strauss, 1990:31/40.) Die vergelyking mis daarom die hele punt. Dit gaan oor die beskermingswaardigheid van regte op grond van die unieke menslike aard van die embrio. Wat ook al van menslike ouers afstam is 'n mens (Noonan, 1977:12/3), maar Kuhse en Singer (1982:61) meen: "It is ... far inferior to a tadpole in respect of all characteristics that would be regarded as morally relevant". Die sjimpansee, vark en rot het volgens hulle ook 'n unieke genetiese kode maar dit gee hulle geen aanspraak op morele status nie. Dit gaan hier natuurlik oor die feit van die uniekheid van die menslike spesie in onderskeiding van die dier.

Samevattend kan 'n mens by bevrugting as kriterium opmerk dat dit nie sonder sy probleme is nie. Die gewone beswaar is dat baie sigote nooit inplant nie maar spontaan aborteer. Hierop kan 'n mens reageer deur daarop te wys dat al bestaan die moontlikheid van spontane aborsie, 'n mens tog met (genetiese) sekerheid kan beweer dat bevrugting die begin van die indiwidualiteit en identiteit van ' $n$ mens met potensiaal is.

Hoewel pro life 'n minderheidstandpunt in die wêrelddebat is, is die klem daarvan op bevrugting as enigste nie-arbitrêre kriterium die enigste eties-regverdigbare standpunt. Omdat hierdie kriterium die morele vryheid van die mens ten opsigte van die manipulering van die fetus aan bande lê, het dit geen status by die indiwidualistiese liberalisme nie.

\subsection{Inplanting (voltooi ongeveer die 6de tot 10de dag)}

As bevrugting as kriterium verwerp word omdat sigote spontaan verlore gaan, is inplanting 'n meer gewilde kandidaat vir die bepaling van morele status. Indien hierdie 
kriterium gebruik word, bied die intra-uterine apparaat geen morele probleem nie. As dit eties waterdig is dat menslike lewe eers by inplanting begin, sou 'n mens probleemloos navorsing op embrio's kon doen vir ongeveer die eerste 10 dae, maar die keuse van hierdie argument moet die feit van die kontinue ontwikkeling van die sigoot ignoreer. Die fokus word nou verskuif van die genetiese indiwidualiteit van die sigoot na die inplanting as proses op die kontinuum van lewensontwikkeling.

'n Mens kan hier natuurlik ook met 'n retrospektiewe blik werk en sê dat alle mense wat nou bestaan, se indiwidualiteit by bevrugting begin het en nie by inplanting nie.

\subsection{Die verskyning van die primitiewe strook (14de/15de dag)}

\subsubsection{Principled pragmatism}

Die kriterium van die verskyning van die primitiewe strook word tans taamlik algemeen gebruik. Dit was reeds die geval by die Leeds-kongres, waar onder andere Dunstan verwys het na die primitive streak as kriterium vir die afgrensing moreelneutraal/moreel-waardevol. Die verskyning van die primitiewe strook op die embrio val saam met die moontlikheid van orgaandifferensiëring. Dit dui volgens hom die begin van indiwidualiteit en dus morele status aan (Dunstan, 1986:56).

Dunstan (1988:38) eis aan die een kant eerbied op vir die 'organisme', ook vir die tydperk 1-14/15 dae (soos op alle stadia), maar beskou dit tog moreel só neutraal dat navorsing sonder gewetenswroeging daarop gedoen kan word. Ook hy gebruik die term pre-embrio vir hierdie stadium van embrionale ontwikkeling. Hy verdedig sy standpunt oor navorsing op embrio's verder deur te beklemtoon dat die doodmaak van pre-embrio's nie "at random" geskied nie, nie met "malicious intent" gebeur nie, dat dit instrumenteel is in die verligting van pyn en dat dit vir enige nugter-denkende mens duidelik behoort te wees dat 'n pre-embrio onmoontlik nie kan aanspraak maak op dieselfde morele status as 'n menslike persoon nie. Hy wil nie "useful research of potential human benefit including the chances of successful pregnancy" inhibeer nie (Dunstan, 1988:14). 'n Positivisties-pragmatisties-utilitaristiese paradigma help hom om aan die wetenskap 'n eties-neutrale lewenspan van 15 dae te gee om met die nodige respek embrio's dood te maak ter wille van navorsing ingestel op die gelukkige gevolg van fertiliteitsbehandeling. Hy noem sy paradigma principled pragmatism (Dunstan, 1988:16). Binne hierdie paradigma word die gesag van die Skrif vervang met dié van statistieke oor mense se morele oordele, met tradisies van die Westerse filosofie en die Engelse reg (Dunstan, 1988:14). Vir Dunstan (as teoloog!) is wetenskaplike utiliteit in hierdie verband meer belangrik as 'geloofsproposisies'. Hy gebruik geen enkele argument wat geloof in die Skrif veronderstel nie. 


\subsubsection{Wat is 'n pre-embrio?}

Die Etiese Komitee van die Amerikaanse Fertiliteits-vereniging definieer 'n preembrio as

a product of gametic union from fertilization to the appearance of the embryonic axis. The preembryonic stage is considered to last until 14 days after fertilization. This definition is not intended to imply a moral evaluation of the preembryo (Kempers, 1986:vii).

Dit val op dat hier van 'n pre-embrio gepraat word sonder om die morele implikasies daarvan vir eie rekening te neem. Hiervolgens is 'n pre-embrio nie 'n embrio nie en is as sodanig moreel totaal iets anders! Die drie etiese probleme wat hier geïdentifiseer word deur hierdie komitee is die volgende: wat daarmee gedoen mag word voor oordrag, of al die embrio's ingeplant moet word en wat met die oortollige embrio's gedoen moet word. Die embrio word genoem "a living, genetically unique entity that has the statistical potential to implant, if transferred to a uterus, and eventually to be delivered as a newborn infant" (Kempers, 1986:29S).

Vir die komitee is daar 'n reuse verskil tussen 'n pre-embrio en 'n fetus in terme van "development and location"! Ontwikkeling het te doen met gedifferensieerde organe, 'n meer ontwikkelde brein en senustelsel en die kapasiteit vir waarneming (Kempers, 1986:30S). Dan word daar verwys na verskillende verslae waaronder dié van die toonaangewende Britse Warnock Komitee om aan te dui dat daar taamlik algemene konsensus is dat daar eerbied aan die pre-embrio verskuldig is maar nie die soort waarop 'n persoon geregtig is nie.

Die verslag gee ook riglyne vir die navorsing op embrio's soos onder andere dat dit alleen gebruik sal word as geen alternatief beskikbaar is nie en dat embrio's nie langer as 14 dae na bevrugting aangehou behoort te word vir navorsing nie (Kempers, 1986:57S).

\subsection{Breinfunksie of waarnemingsvermoë}

Volgens Dunstan $(1988: 19,59)$ het 'n mens dan na die 15 de dag nie meer met 'n preembrio te doen nie maar met 'n egte embrio en is daar sprake van indiwidualiteit. Orgaandifferensiëring vind nou plaas. Die neurale plaat begin vorm op die 18de dag. Die neurale buis vou oop rondom die 21 ste dag en die hele sentrale senustelsel is basies teenwoordig teen die 26ste dag. Die eerste tekens van 'n serebrale korteks verskyn op ongeveer 6 weke en 'n beduidende vermeerdering van breinselle begin op 8 weke. Vir die ontwikkeling van die mens is breinfunksie van die grootste belang. Al sy vermoëns hang immers met sy rasionaliteit saam. 
John Marshall is krities oor die gebruik van breinfunksie of waarnemingsvermoë in hierdie debat juis omdat dit 'n arbitrêre keuse is. Hy oordeel (anders as gewoonlik) dat breinfunksie gekies word as kriterium omdat dit voorwaarde is vir die ervaring van pyn. Solank jy nie leed (harm principle van Mill) aandoen nie, is daar geen probleem nie. Breinfunksie word volgens hom egter bloot gekies om die eintlike probleem te omseil, naamlik die probleem rondom persoonwees. 'n Mens sou die kriterium van pyn-ervaring ook by diere kon gebruik maar dit kom neer op 'n miskenning van die "peculiarly human status" van die menslike embrio.

If the embryo is thought to be a person, in the sense of someone who cannot be used as a means to an end, the fact that what is being done can be done without pain becomes an irrelevance (Marshall in Dunsian, 1988:61).

Krities moet 'n mens ook by hierdie kriterium opmerk dat die embrionale ontwikkeling kontinu is. Geen stadium, ook nie dié stadium van die ontwikkeling van breinfunksie, kan dien as morele waterskeiding vir morele status nie (vergelyk Häring, 1982:84, 101).

\subsection{Fetale beweging}

Vroeër was die eerste waarneming van die bestaan van die fetus gekoppel aan die moeder se eerste ervaring van beweging in haar liggaam. Fetale beweging (quickening) maak die verhouding tussen moeder en kind meer werklik: daar is 'n respons. Die band wat deur gevoel geregistreer word, het eksistensiële dimensies. Met die ontwikkeling van sonarondersoeke het 'n opwindende ervaring moontlik geword: die sigbare belewenis van die kind na wie se geboorte uitgesien word.

Die verhouding tussen ouer en kind is egter nie van die bloot sintuiglike ervarings afhanklik nie. Wanneer ouers aflei of verneem dat daar ' $n$ kind op pad is, beleef hulle hulleself as ouers, ouers wat in verhouding staan met hul ongebore kind.

Wanneer aborsie nou verdedig word tot op ongeveer 14 tot 16 weke omdat daar nog geen sosiale verhouding tussen moeder en kind is nie, beteken dit dat die feit geïgnoreer word dat 'n ontwikkelende mensie reeds tevore bestaan het. Om 'n sosiale verhouding op grond van die voel van lewe as kwalifikasie vir voortbestaan te beskou, kan in die lig van die kontinuïteitsidee nie aanvaar word nie.

\subsection{Besieling of animasie}

Chronologies is die plasing van die besielingskriterium 'n probleem. Selfs as aanvaar word dat dit eintlik maar gaan oor die ontvang van 'n rasionele siel, is enigiets van 40-90 
dae moontlik, soms selfs die derde trimester.

Die besielingsteorie gaan sover terug as die Orfiek in die 7de eeu v.C. Dit het sy plek in die Westerse filosofie gekry deur die invloed van Plato en Aristoteles en in die Christelike teologie deur die invloed van Thomas Aquinas. Die Christendom het nie die idee van die preëksistensie van siele uit die Orfiek oorgeneem nie, maar wel die leer van die psigokreasianisme.

Die probleem van die psigokreasianisme is dat dit die dualistiese mensbeeld gevestig het in die Christelike denke. Die rasionele siel word ewig, onsterflik, heilig, goddelik en onvermietigbaar genoem. Die liggaam daarteenoor word beskou as die setel van die sonde, as die kerker van die siel en as deur en deur sterflik. Die eenheid van menswees is op hierdie wyse in gedrang gebring. So word die idee gevestig dat ouers verantwoordelik is vir die liggame van kinders en dat God op 'n sekere stadium 'n rasionele siel vir die embrio inskep wat tegelyk die beginpunt van sy morele status beteken.

Die reformatoriese teologie en filosofie het hom pas in die afgelope dekades ontworstel aan die dualistiese mensbeeld en besef dat die verkeerde (skolastieke) formulering van probleme soos: 'Wanneer kry die mens 'n siel?', 'Is die beeld van God eksklusief geleë in die siel?' en 'Het die mens 'n onsterflike siel?', lei tot die verkeerde antwoorde. Die Bybel ken hierteenoor net konkrete mense wat as totale mense na die beeld van God geskape is, dit leer 'n ewige lewe vir die totale mens en dit aanvaar dat met bevrugting ' $n$ totale mens op die spel is en nie 'n siellose liggaam nie.

Heyns beklemtoon na aanleiding van Psalm 139, Jeremia 1:5 en Psalm 57:7 die kontinuïteit tussen die mens se lewe in die moederskoot en daarna. Hy wys daarop dat hierdie Skrifgegewens nie onderskei tussen die afsonderlike begin van die liggaam en die begin van die siel nie. 'n Probleemstelling wat onderskeidelik vra na die oorsprong van die liggaam en van die siel misken die Bybelse leer oor die eenheid van die mens.

Met betrekking tot die biologiese ontstaan van die mens, mag die vraag: hoe lank is die embrio net liggaam en wanneer kom die siel in die embrio in? nie gevra word nie. As die embrio lewe, kan dit geen ander lewe as menselewe wees nie ... (Heyns, 1986:214).

Een van die baie positiewe ontwikkelinge in die Rooms-Katolieke kerk sedert die Tweede Vatikaanse Konsilie is dat dit afgestap het van die besielingsteorie in sy Thomisties-Aristoteliese gedaante. In 1982 reeds het Pous Johannes Paulus II in 'n rede voor bioloë die eksploitering van die menslike wese van bevrugting tot die dood, hoe edel die motief ook al mag wees, eksplisiet veroordeel. In hierdie rede verwys hy geen enkele keer na die besielingsteorie nie (Dunstan, 1986:79). In die nuwere uitsprake word psigokreasianisme nie meer gebruik nie. Die besielingsteorie behoort tot die geskiedenis en verdien geen oorweging in die debat oor die morele status van 
die menslike embrio nie. Ongelukkig leef die trigotomistiese sielsleer met gepaardgaande aanvaarding van 'n toenemende morele status, voort in die idee dat die menslike embrio in die eerste trimester geen morele status het nie maar dat dit in die tweede en veral derde trimester op meer beskerming geregtig is.

\subsection{Lewensvatbaarheid}

Lewensvatbaarheid word in die reg op 28 weke gestel (medies op 22 weke). Omdat die moontlikheid dan bestaan om buite die moederliggaam te oorleef, is dit die mees aanvaarbare kriterium vir morele status. As gevolg van die ontwikkeling van die mediese wetenskap en tegnologie word die tydstip van lewensvatbaarheid steeds vervroeg. Dit is egter nie waar dat byvoorbeeld die Britse wetgewing se liberalisering van abortus tot op 28 weke gegrond is op oorwegings wat eksklusief te doen het met die morele status van die embrio (verkry deur verwerwing van lewensvatbaarheid) nie. Die eintlike rede is dat die lewe van die moeder in die gedrang kom rondom 28 weke.

As kriterium vir morele status is lewensvatbaarheid net so onaanvaarbaar as enige ander stadium. Regstatus en morele status behoort te oorvleuel. Waarom sou 'n fetus eers op 28 weke geregtig wees op liefde en eerbied vir sy lewe en menswees? Waarom moet die talle fetusse jonger as 28 weke wat lewensvatbaar is op grond van mediestegnologiese ontwikkeling, regstatus verbeur?

\section{$3.8 \quad$ Geboorte}

Geboorte beteken 'n onafhanklike bestaan vir die baba en 'n meer sigbare bestaan wat nuwe moontlikhede skep vir sosiale verhoudings. Geboorte is ook 'n kriterium vir indiwidualiteit en identiteit. In die humanistiese debat loop geboorte uit op (die ontvouing van) 'persoonlikheid'. Die probleem is egter dat die baba nog geensins voldoen aan die kriteria vir persoonwees wat straks ontleed sal word nie. In hierdie verband moet klem gelê word op die kontras in morele status tussen 'n ongebore en 'n gebore menslike fetus. Wat het werklik aan die fetus as fetus verander wat so 'n drastiese sprong in morele status moontlik maak?

\section{PERSOONWEES AS ACHILLESHIEL VAN DIE HUMANISTIESE BIO- ETIEK}

Omdat die reg oor die algemeen die gebore kind beskou as persoon met regstatus en die status dikwels aan die ongebore kind in die eerste en tweede trimester ontsê word, 
is dit belangrik om enkele argumente hieroor aan die orde te stel.

\subsection{Mary Anne Warren}

Volgens die liberalistiese interpretasie het 'n fetus geen regstatus en geen morele status nie. 'n Morele gemeenskap sluit alleen persone in en 'n fetus is geen persoon nie.

Mary Anne Warren (1977:20) se vyf kriteria vir persoon-wees word wyd aanvaar:

- Bewussyn van objekte en gebeure in en buite homself.

- Beredeneringsvermoë in probleemoplossing.

- Self-motiverende aktiwiteit.

- Kommunikasievermoë.

- Selfbewussyn en die teenwoordigheid van selfkonsepte.

Warren beklemtoon die absolute outonomie ('reg') van die vrou sodanig dat die fetus geen reg op lewe het as die moeder so sou besluit nie. Nog die feit dat die fetus lyk na 'n persoon, nóg die feit dat dit die potensiaal het om 'n persoon te word, gee hom enige reg op lewe. Gevolglik sal die moeder se reg op gesondheid, geluk en vryheid altyd die reg op lewe van selfs 'n vol-ontwikkelde fetus, oorstyg.

And thus, in the absence of any overwhelming social need for every possible child, the laws which restrict the right to obtain an abortion, or limit the period of pregnancy during which an abortion may be performed, are a wholly unjustified violation of a woman's most basic moral and constitutional rights (Warren, 1977:24).

\subsection{Michael Tooley}

Michael Tooley se artikel oor "Abortion and infanticide" $(1981: 59,83)$ het besondere aandag getrek in die debat. Hierin gaan hy ook in op die onderskeidende kenmerke van persoon-wees wat kan dien as kwalifikasie vir die reg op lewe. Hy verwerp die voel van lewe en die stadium van lewensvatbaarheid as relevante kriteria vir die bepaling van regstatus en morele status. In die kontinu-ontwikkelende mens is dit moreel onbeduidend en enige punt gedurende die swangerskap is arbitrêr. Op die vraag of geboorte nou 'n relevante kriterium is antwoord Tooley ontkennend en stel dat dit 'n 'wild contention is om te beweer dat pasgebore babas persone is. 'n 'Organisme' het 'n reg op lewe slegs as hy'n selfkonsep het. Daar moet egter ook 'n subjektiewe behoefte aan so 'n reg aanwesig wees by sodanige persone; dus het pasgebore babas geen reg op lewe nie. Potensialiteite van organismes is irrelevant as dit kom by hulle reg op lewe. 
Die reg op lewe word dus eers verwerf na geboorte. Tooley verwys na gevalle waar oorerflike siektes kindermoord noodsaaklik maak! Dit is gewoonlik kort na geboorte duidelik of 'n kind aan so 'n siekte ly en omdat geen selfkonsep op daardie stadium teenwoordig is nie, is kindermoord geen morele probleem nie. Hy stel voor dat kindermoord toelaatbaar moet wees vir die eerste week na geboorte. Hierdie voorstel kan volgens hom gewysig word sodra die sielkundiges 'n punt vasgestel het waar 'n menslike 'organisme' besef dat hy 'n wese is met kontinue subjektiewe ervaringe (Tooley, 1981:79).

\subsection{Jane English}

In 'n artikel oor "Abortion and the concept of a person", kom Jane English (1981:8391) tot die slotsom dat 'n enkele kriterium nie reg kan laat geskied aan die konsep van persoon nie. In sekere gevalle is aborsie reg en in andere verkeerd, afgesien van die vraag of die fetus 'n persoon is. Sy verwys na Mary Anne Warren se vyf kriteria, na Tooley se kriterium van die besit van 'n self-konsep, na Paul Ramsey wat dit vind in die DNA-kode en John Noonan se idee dat wat deur mense gegenereer is, mense is. Vir haar behels 'n persoon "a cluster of features".

Sy verwys na kriteria soos die biologiese (afstammeling van mense), die psigologiese (waarneming, selfkonsep, taalvermoë, humor, twyfel!), rasionele (beredeneringsvermoë), sosiale (vermoë om te sosialiseer, simpatiseer, lief te hê) en juridiese (vermoë om wetlik op te tree, kontrakte te sluit, burgerskap te ervaar).

Natuurlik, sê sy, is dit onvolledig, maar wat belangrik is, is dat geen kern van noodsaaklike, toereikende eienskappe aangedui kan word om persoonwees te kwalifiseer nie. Volgens haar is dit dus onmoontlik om te bepaal of 'n fetus 'n persoon is of nie, maar dit is ook nie nodig nie: daarsonder kan 'n reg op lewe steeds verdedig of ontken word. Sy gebruik die idees van selfverdediging en van persoonlike voorkoms om haar standpunt te staaf.

Wanneer iemand aangeval word, is selfverdediging gerade. Wanneer die moeder die fetus ervaar as 'n ernstige bedreiging, mag sy haar verdedig deur die fetus te laat aborteer al is dit onskuldig. Andersyds kan abortus eties beoordeel word op grond van die feit dat fetusse "person-like non-persons" is. In die begin is dit 'n stel gene. Hoe later hoe meer $l y k$ die fetus na ' $n$ mens. Fisiese identiteit is in die algemene ervaring van mense toereikend vir persoonlike identiteit. Liggaamlikheid speel 'n baie belangrike rol in ons houding teenoor persone. Aborsie kan dus verkeerd wees op grond van die (uitwendige) ooreenkoms tussen fetus en persoon. In die vroeë maande van verwagting sal aborsie dus toelaatbaar wees, in die middelmaande met groter persoonlike voorkoms regverdigbaar en in die laaste maande onaanvaarbaar. 
Met hierdie drie voorbeelde word volstaan. Die debat is vol verwysings na hierdie persoonsvermoëns en die gebruik daarvan is redelik stereotiep.

\section{DIE CHRISTELIK-WYSGERIGE ANTROPOLOGIE EN MENSWEES AS PERSOONWEES}

\subsection{Die beeld van God}

Soek 'n mens na 'n sentrale metafoor vir menswees in die Christelik-etiese denke, is daar net een moontlikheid: die 'beeld van God'. Die keuse van hierdie oortuiging is voor-wetenskaplik van aard. Die metafoor van die beeld van God word in die Christelike etiek (wetenskaplik) gebruik om die unieke waardigheid van die menslike persoon en die onaantasbaarheid van sy lewe te verduidelik. Genesis $1: 26,27$ gee die mens se status aan as beeld en verteenwoordiger van God. In Genesis 9:6 word moord veroordeel deur dit in verband met die beeld van God te bring. Omdat elke mens in sy persoon God verteenwoordig, is sy lewe sakrosant (letterlik heilig en onaantasbaar).

Met verwysing na Psalm 139 en Jeremia 1:5 kan mens wel van 'n misterieuse betrokkenheid van God by elke stadium van embrionale ontwikkeling praat. Psalm 139 gaan juis oor die heerlikheid van die soewereine God wat ontvou in sy almag, alomteenwoordigheid, alwetendheid en alwerksaamheid. Dit word ook van toepassing gemaak op die ontwikkeling van voorgeboortelike lewe. Natuurlik spel dit nie uit dat die mens van bevrugting af 'persoon' is in die modern-humanistiese sin daarvan nie. Teologies staan dit vas dat daar geen eksplisiete Skrifuitspraak is oor wanneer menslike lewe begin nie (Heyns, 1986:214).

Die psalm gebruik die term 'ongevormd' maar beslis nie om die embrio (soos in Middeleeuse debatte oor 'ongevormd' en 'onbesield') te beroof van sy morele waarde nie. Inteendeel, die almagtige God se betrokkenheid by die daaglikse ontwikkeling van embrionale lewe word beklemtoon met die metafoor van boekstawing. Elke dag se ontwikkeling is in God se boek opgeteken. Daar is geen eksegetiese rede om bevrugting en inplanting of dan die ontwikkeling van die eerste 15 dae, hiervan uit te sluit nie.

As Genesis 1 en 9 gelees word saam met die verhewe Psalm 139 oor die status van ongebore menslike lewe in die oë van God, het mens die verwysingsraamwerk ('geloofsproposisies, 'metafisiese beginsels'!) vir die hantering van die morele status van die menslike embrio. Die Skriftuurlike eis om die naaste lief te hê soos jouself moet binne hierdie konteks ook op die ongebore menslike lewe van toepassing wees (vgl Mat. 22:39, Mark. 12:30,31, Mat. 7:12). 
Die sigoot/embrio/fetus is 'n mens, 'n ontwikkelende mens, 'n mens wat God beklee met die waardigheid van God se verteenwoordiger. Die embrio se lewe is onaantasbaar. Om embrio's wederregtelik dood te maak is om moord te pleeg. Dat die gebrokenheid van die bestaan aborsies as 'n onaanvaarbare, mindere euwel (of egte kompromie) noodsaaklik maak in sekere gevalle, is vanselfsprekend, maar dan is doodmaak ook nie sonder skuld nie. Thielicke (1979:242) beklemtoon dat nóg die neem van die lewe van die embrio met sy vreemde waardigheid as beelddraer van God, nóg die neem van die moeder se lewe sonder skuld is.

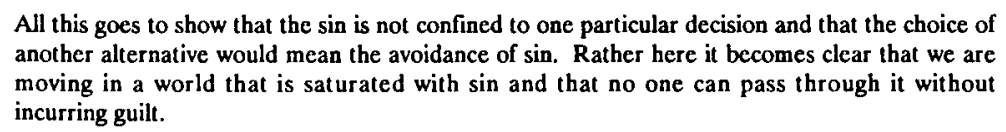

All this goes to show that the sin is not confined to one particular decision and that the choice of another alternative would mean the avoidance of sin. Rather here it becomes clear that we are moving in a world that is saturated with sin and that no one can pass through it without incurring guilt.

Daarom is dit 'n etiese eis dat in mediese navorsing vir sover dit moontlik is, steeds gesoek word na alternatiewe indien die doodmaak van embrio's implisiet deel van die navorsing is.

Die beeld van God in die mens is geleë in 'n beperkte ooreenkoms tussen die persoon van God met al sy vermoëns en die persoon van die mens met al sy vermoëns. Volgens God se wet vir of bedoeling met menswees, is die beeld van God nie deur die sondeval vernietig nie en bly hy menslike persoon met vermoëns soos om te kan liefhê, glo, heers en skep. Feitelik is 'n mens alles behalwe die ewebeeld van God. Sy persoonlikheid en vermoëns vertoon 'n mindere of meerdere gebrokenheid. Dit is weliswaar nie 'n totale gebrokenheid nie omdat God in Christus die skepping dra en die kwaad teëhou. In Christus as Verlosser kan die mens die beeldskap van God weer herwin. Die beeldskap bly ten dele tot die jongste dag. Voleinding beteken 'n nuwe mens, 'n volle beelddraer, op 'n nuwe aarde waar God alles in almal is.

Intussen is die mens geroepe tot 'n lewenstyl van liefdesdiens. Met sy hele persoonlikheid en al sy vermoëns is hy geroepe om God en medemens in liefde te dien. Die beeld van God ontvou deur gehoorsaamheid aan die sentrale religieuse liefdesgebod en die sin van die bestaan is geleë in liefdesdiens. Dit is ook 'n etiese eis wat vir alle wetenskaplike navorsing geld.

\section{2 'n Holistiese mensbeeld}

Konkrete mense kan nie in dele verdeel word nie. Niemand kan 'n voorstelling maak van 'n persoonlikheid sonder om so ' $n$ indiwidu se liggaamlikheid in te sluit nie. Die mens is 'n eenheid en 'n uitdrukkings soos 'Ek is my liggaam' en 'Menswees is lewendwees-in-liggaamlikheid' is geyk in die wysgerige en teologiese antropologie. In die 
mediese etiek is die eis van die holistiese benadering van die pasiënt of kliënt meer as bekend.

Die mensbeskouing wat in hierdie artikel gehanteer word, gaan uit van 'n onderskeiding (nie skeiding) tussen die kenbare mens en die onkenbare mens, tussen persoon en persoonsentrum. Die idee van ' $n$ persoonsentrum of religieuse hart is ' $n$ openbaringsfeit. Die kenbare persoon sluit in alles wat van die mens geken kan word - as liggaamlike wese met stoflike, biotiese, psigiese en normatiewe kante. Dit sluit in wat introspektief geken kan word en deur die Dieptesielkunde na vore gebring is en nog kan word. Die beeld van God dek dan ook hierdie totale mens: hart en liggaam. Persoon verwys na die mens in sy totaliteit.

Die vermoëns wat volgens humanistiese oortuiging persoonwees kwalifiseer, is binne hierdie raamwerk vermoëns van die normatiewe struktuur (verkieslik nie aktstruktuur nie) van die menslike persoon.

Om dus te sê dat die mens 'n psigo-somatiese eenheid is, is in hierdie paradigma 'n verskraling. As wel na die mens verwys word as 'n twee-eenheidswese word iets anders bedoel. Die persoonsentrum of religieuse hart is as allerlaaste 'subjektiwiteit' aan alle objektivering onttrokke, maar die konkrete liggaamlike mens met sy (minstens) vier onderskeibare strukture, is kenbaar.

Die liggaamlike mens is saamgestel uit stowwe en deel met die planteryk in biotiese lewe. Hy is ook 'n psigiese wese met sintuiglike waarnemingsvermoë, instinkte soos seksualiteit, ensovoorts. Ten spyte van ooreenkomste met die dier, verskil die mens egter in talle opsigte van diere. Menseselle en diereselle en planteselle mag veel in gemeen hê, maar die potensiaal van byvoorbeeld 'n dieresel is minimaal in vergelyking met 'n mensesel. Die mensesel berg transendente geheime:

... only the human germ-cell ... refers to the mystery of the spiritual centre of human existence, which transcends all temporal structures. In other words, the qualifying function of a nonhuman germ-cell is entirely dependent on the individuality-structure of the being destined to develop from it genetically. Only the germ-cell of a plant is biotically qualified ... (Dooyeweerd, 1957:645)

Die mens is 'n normatiewe wese. (Let wel, binne die reformatoriese antropologie is dit 'n ontoelaatbare reduksie om na die mens as 'n rasionele wese te verwys!). Normatief verwys na die tipies menslike vryheid van persoonsvermoëns soos om logies te dink, in taal te kommunikeer, om esteties te kan skep en geniet, om eties te kan liefhê en eerbiedig, om sosiaal in verhouding tot ander te kan staan en om te kan glo. Dit verwys ook na die verantwoordelikheid om hierdie vermoëns of vryhede op 'n sekere wyse te hanteer. Omdat die mens 'n normatiewe wese is, verskil sy seksuele lewe dan 
ook van dié van 'n dier daarin dat dit onder leiding van onder andere liefdesnorme staan.

Die holistiese mensbeeld geld vanaf bevrugting tot en met sterwe. Dat al die mens se vermoëns potensieel reeds teenwoordig is in die sigoot, kan op nog 'n ander manier gestel word:

Geen Putagoras, Cantor, Beethoven, Bach, Rembrandt, Chagall, Rodin, Einstein, Bohr, Aristoteles, Kant, Calvyn, Barth, Gaudi, Wren, Shakespeare of Van Wyk Louw het hul lewe in die wêreld anders begin as deur die eenwording van sperm en eisel nie. Al die potensiaal was oorspronklik opgesluit in die genetiese kode van die sigoot. Die omgewing kon beïnvloed wat daar was, maar dit kon niks toevoeg nie. Hierdie biotiese kontinuum as substraat van al die geestelike potensiaal van die mens, maak dit onmoontlik om die term persoon sodanig te hanteer dat dit eers gestalte kry'n ruk na geboorte.

By hierdie potensiaal van die mens moet nog een besondere eienskap beklemtoon word: dat hy die tyd oorstyg, dat daar vir hom 'n ewige lewe bestaan. Die feit dat die mens 'n meer-as-tydelike wese is, word meermale uitgedruk deur te verwys na sy transendensie. Hierdie transendensie is nie beperk tot die mens se siel of hart nie maar sluit sy totale menswees in (1 Kor. 15).

Die implikasies van hierdie paar antropologiese lyne is dat die mens ook vir sy kleinste besluite transendent verantwoording aan God verskuldig is. Hierin lê daar 'n belangrike en noodsaaklike kontrole op die mens se ongelooflike vermoë om grille en giere as norme te rasionaliseer en om egoïsme as altruïsme voor te stel.

\section{3 'n Nuwe dualisme?}

In die medies-etiese debat word na die embrio verwys in eksklusief biotiese terme. Die pre-embrio het min/geen morele status nie, want dit is niks meer as 'n biotiese entiteit of weefsel of protoplasma nie. Maar omdat morele en regstatus vir rasionele, outonome indiwidue van belang is, moet noodwendig aanvaar word dat die mens iewers op die pad van bevrugting na menswording 'n persoon word. Hierdie persoonwees word getoets aan 'n paar kriteria wat almal wentel om rasionaliteit.

Die klem wat op persoonsvermoëns gelê word in die huidige debat, is myns insiens niks anders nie as 'n terugval op 'n ontoelaatbare dualisme tussen liggaamheid en persoonsvermoëns. Daar is selfs niks nuuts aan hierdie dualisme nie. Die enigste verskil is dat die 'siel' in 'rasionele siel' (Aristoteles, Plato, Thomas) soek geraak het in die 
Persoonwees en die morele status van die menslike embrio

humanistiese fulminering teen die reste van die metafisika.

In aansluiting by Teresa Iglesias (1984:35) kan die verwerping van hierdie dualistiese visie soos volg geformuleer word:

By the principle of unity is meant that human beings ... are just one entity, one being, and not a composite of two things. They are not first physical organic bodies with (at a later stage) personhood added to them by self-consciousness, making them human beings and persons. They are not human organisms first and persons only subsequently, in virtue of the advent of a 'soul' or consciousness.

Die mens se gene en liggaamlike vorm staan nie los van sy persoonsvermoëns nie. Die mens ervaar sy persoonwees juis deur sy eiesoortige liggaamlikheid. As liggaamlike mens tree hy op 'n persoonlike wyse teenoor ander op. Iglesias lê klem op die feit dat slegs mense kultuurwesens is wat hulle uitleef in terme van taalaktiwiteit, religie, politiek, kunsskepping, kunswaardering en tegnologie.

Natuurlik is dit waar dat die mens later die vermoëns ontwikkel van selfbewussyn en selfbepaling, maar dit verduidelik nie die oorsprong en ontwikkeling van hierdie vermoëns nie. Die potensialiteite waarvan deurgaans gepraat word is in werklikheid aktueel teenwoordig en sal onder normale omstandighede min of meer ten volle verwesenlik word in die lewe van 'n volwassene.

Daarom besit die sigoot 'n persoonlike lewe as persoonlike subjek. Die ontwikkeling van die 'entiteit' is inderdaad 'n proses, maar die 'entiteit' self is geen proses nie. Op enige spesifieke tydstip is dit mens in toto of glad nie. Die laaste grond vir die morele waarde van ' $n$ wese is sy bestaan en nie vervlietende aktiwiteite en begeertes nie. Wording het sy basis in bestaan. Basiese regte en verpligtinge soos die reg om nie doodgemaak te word nie en die plig om nie 'n onskuldige menslike wese dood te maak nie, is gebaseer op wat mensewesens is en nie op 'n spesifieke staat van bewuste begeertes nie (Iglesias, 1984:36).

As samevattende oordeel by hierdie paragraaf kan gestel word dat 'n sigoot (bevrugte eisel voor verdeling) ' $n$ menslike persoon is met potensiaal. Hy het indiwidualiteit en identiteit reg van die begin af. Om 'n wig in te dryf tussen liggaamlikheid en persoonwees is antropologies en eties ontoelaatbaar en misken die waarde wat elke beelddraer van God van die begin af het. 


\section{IDEOLOGIESE TEGNISISME EN DIE VERLIES VAN MORELE STATUS}

Die stryd in die debatte oor mediese etiek word meesal nie besleg deur 'wetenskaplike' feite nie, maar deur ideologieë wat aggressief bemark word. As Dooyeweerd die moderne humanisme ontleed, tipeer hy die grondmotivering daarvan as 'n dialektiek van natuurbeheersing en vryheidsbelewing.

The control motive is intensely and religiously tied to the new freedom motive which originated in the humanistic religion of personality, the cult of autonomous man who desires to make himself absolutely independent of every authority and of every 'supranatural power' in order to take his fate into his own hands. Like Copernicus, who brought about a revolution in the traditional picture of the universe with the earth as its centre, so humanism brought about a revolution in the religious valuation of buman personality. In the humanistic conception, this personality is the measure of all things, including religion (Dooyeweerd, 1979:152).

'n Sentrale motief in enige ideologie is dié van mag. Medies-tegniese mag het sy eie gevare. Visagie (1990:117) verwys na ideologie as:

... those powers and paradigms (currents, movements, motives) that operate within a given socio-cultural space, and that invite a commitment to certain absolutized values and ideals which can be regarded ... as dangerously repressive and distorting - both for human knowledge and for human freedom.

Die humanisme glo in die wetenskap waarvan die fondamente in outonome, rasionele denke lè. Die humanisme se mag is natuurwetenskaplike beheersingsmag en vind gestalte in die tipies twintigste-eeuse tegnisisme. Dit is hierdie tegnisisme wat die vryheid van die (ook ongebore) mens bedreig.

Wetenskaplike kennis is in wese abstrak van aard. Die reduksies wat dit (sedert die Verligting) meebring, moet steeds as reduksies geïdentifiseer word. Omdat dit nie gebeur nie, het tegnisisme 'n kultuurkaraktertrek van ons tyd geword. Wie wetenskapsbeoefening as beheersingsinstrument hanteer, moet noodwendig die greep op die volle werklikheid van onder andere menswees verloor. Al glo die wetenskap hartgrondig dat dit 'n steeds groter greep op die werklikheid verkry, lei dit die denke op die reduksionisticse weg (Schuurman, 1989:1/7).

In hierdie artikel is aangedui hoe medies-tegniese mag lei tot standaardprosedures en hoe hierdie ingrepe, as hulle eers gevestig is, lei tot volgendes. Telkens word die volle konteks van die medies-etiese probleme egter buite rekening gelaat. In hierojie verband moet verwys word na die noodsaaklikheid van liefdesverankerde menslike seksualiteit en na duursame gemeenskapstrukture waarbinne die liefdeslewe van die mens kan gedy.

Die makro-idiologie van ons tyd is die reeds vermelde ideologie van die vryheid en 
outonomie van die indiwidu. Binne hierdie ideologie speel vrye seksuele uitlewing 'n oorheersende rol. Seks is by uitstek 'n meganisme van die mens se vryheid. Om hom op hierdie punt aan te spreek, val totaal uit toon uit. Die mens is vryheid. Vryheid is seks. 'n Mens soek tevergeefs in populêre en wetenskaplike artikels na verwysings na verantwoordelike seksualiteit. Sou dit ter sprake kom, sou dit onmiddellik die beskuldiging van paternalisme, morele chauvinisme of puriteinse verkramptheid ontlok. Intussen word die kwaliteit van die gemeenskapslewe juis in gedrang gebring deur antinormatiewe seks. Gevolglik word kontrasepsie in die moderne Westerse gemeenskap vervang met aborsie. As eindproduk van die kultuurontwikkeling van ongeveer 26 tot 27 eeue beïndruk dit nie.

Omdat seksualiteit gestroop is van sy skeppingsmatige struktureel verskansde liefdeskonteks, moes die wetgewer ook uiteindelik hierby aanpas. Dit kan geillustreer word met verwysing na die twee landmerk-hofuitsprake in Amerika naamlik die reeds genoemde Roe vs Wade en dan ook Planned Parenthood of Missouri vs Danforth.

In albei gevalle kan onderskeidelik die vrou of dogter op advies van haar dokter en onafhanklik van onderskeidelik die man of die ouers, besluit oor 'n aborsie. Die vrou en minderjarige dogter het vetoreg (Leiser, 1981:33,57). Op hierdie wyse word die huwelik en gesin gerelativeer tot iets onbeduidends deur die pa en ouers uit te rangeer. Meer nog: in plaas van die gemeenskapsmoraal te eerbiedig, neem die reg deel aan die ondergrawing daarvan.

Hierteenoor pleit die Christen Geneesherebond in sy etiese kode vir die volgende:

To uphold marriage as a lasting bond, being the divinely appointed means for the care of children, the security of the family and the stability of society.

To recognise that sexual intercourse is intended by God only for the marriage relationship and, hence to advocate premarital continence and marital fidelity (Scorer \& Wing, 1979:200).

Dit sal steeds weer beklemtoon moet word dat God se skeppingsordeninge ewig is. Die mens kan nie nuwe ordeninge vir sy seksuele en sy sosiale lewe skep nie. Die distorsie van die ideologie lewer nie die vryheid of die geluk wat dit beloof nie.

Die wetenskap en die tegniek kan baie aan ons geluk doen, maar as dit 'n totalitêre dimensie in ons lewe inneem, verwoes dit ons geluk. Daar is iets beveiligends in om steeds weer terug te keer na die konkrete, voorwetenskaplike belewing van sake wat seksualiteit en voortplanting raak.

'n Gesin word nie in 'n spreekkamer of teater gebou nie. 
Om van 'n embrio of selfs ' $n$ menslike embrio te praat, is 'n abstraksie. ' $n$ Vrou wat verwag, verwag nie ' $n$ embrio nie, maar ' $n$ kind. Maar dis nie net 'n vrou wat 'n kind verwag nie, dis ' $n$ vader en 'n moeder wat 'n kind verwag. As ouers word hulle in die amp van ouers geplaas die oomblik as hulle hoor of aflei dat hulle 'n liefdeskind verwag. Die raamwerk vir die bespreking van die morele status van die menslike embrio bly steeds die gesin.

Binne so 'n liefdesgemeenskap is ouerskap 'n amp wat met vreugde en dankbaarheid en pligsvervulling ervaar word.

This status means that the "office" of fatherhood and motherhood has been entrusted to the
parents and that they are now enclosed in that circle of duties which obligates them to preserve
that which has been committed to them, but also endowed with a blessing which is to be
received in gratitude and trust - even though it be a gratitude expressed with trembling and a
trust that is won with struggle (Thielicke, 1979:227).

Waar etiek 'n vakwetenskap is wat aktuele probleme ondersoek in die lig van die etiese modaliteit van die bestaan (met as sinkern: liefde, persoonseerbied, persoonsbehartiging, persoonsbehandeling), het die klem in hierdie artikel geval op die deernisvolle, persoonseerbiedigende optrede teenoor ongebore mense. Gevolglik word geoordeel dat vanuit 'n Christelik-wysgerig-etiese gesigshoek daar geen rede bestaan om die Wet op Aborsiewet en Sterilisasie van 1975 te liberaliseer nie. Dit maak ruim voorsiening vir enige moontlike geval waar die noodsaaklikheid van 'n aborsie nie toegeskryf kan word aan persoonlike onverantwoordelikheid nie. Om dit te hervorm, sou beteken om seksuele onverantwoordelikheid met misdaad te beloon.

Daar moet eenvoudig ander metodes gevind word om die sosiale probleme waarop die aborsiepraktyk inspeel, op te los. Hierdie sosiaal-etiese probleme het te doen met seksualiteit en die sinvolle sosialisering daarvan. Die oplossing van sodanige probleem beteken 'n herwaardering van daardie samelewingstrukture wat deur die liefde gekwalifiseer word, naamlik die huwelik en die gesin. Hierdie strukture waarborg van die skepping af 'n oersekuriteit vir persoonlikheidsontwikkeling.

Alle moontlike samelewingstrukture sal ingespan moet word om hul bydrae te maak tot 'n opvoeding tot sinvolle en verantwoordelike en dienswillige liefdesverhoudinge. Daarom kan die gebruik van kontrasepsie nie die hoofdis op hierdie agenda wees nie. So 'n program behels ook dat die reg op privaatheid weer tot sy etiese dimensies teruggesny sal word sodat dit nie langer'n reg op promiskuïteit en eventueel op moord sal wees nie. As die gemeenskap sy emosionele en sosiale sekuriteite steeds beleef binne huweliks- en gesinsverband, bestaan daar 'n morele verantwoordelikheid om hierdie strukture in beskerming te neem en nie te ondergrawe nie. 
Die definisie van 'lyding' wat in hierdie debat soms tot breekpunt (moordpunt) gerek word, moet ook dringend hersien word.

Daar bestaan definitiewe grense vir die manipulering van die ongebore menslike lewe met sy vreemde waardigheid as beelddraer van God. As 'n mens dan moet dwaal, moet dit liefs aan die veilige (etiese of persoonseerbiedigende) kant wees.

Waar mediese tegniek en navorsing voorgee om lyding te verlig of te voorkom, moet gevra word of dit werklik gebeur (by voorbeeld deur aborsie) en of die sin van lyding, as 'n eg-menslike belewenis, ten alle koste genegeer mag word. Naas die utilitaristiese oorweging van die groots moontlike geluk vir die groots moontlike aantal ('n gevolgsetiek), is daar 'n plek vir ' $n$ beginsel-etiek wat nie deur die mens geskryf is nie.

\section{BIBLIOGRAFIE}

BLIJHAM, H. 1984. Bedreigd leven bedreigd bestaan. Amsterdam : Buijten \& Schipperheijn. BROMHAM, D.R., ed. 1990. Philosophical ethics in reproductive medicine. Manchester : Manchester University Press.

CALLAHAN, D. 1977. Abortion decisions: personal morality. (In Mappes, T.A. \& Zembaty, J.S., eds. Social Ethics. New York : McGraw-Hill. p. 24-32.)

DALTON, M. \& BROMHAM, D., eds. 1988. Philosophical ethics in reproductive medicine abstracts. Leeds : University of Leeds.

DIE VOLKSBLAD. 1990. Tot 30 miljoen onwettige aborsies jaarliks. Junie 5, p. 5

DOOYEWEERD, H. 1957. A new critique of theoretical thought. Volume 3. Amsterdam : H.J. Paris.

DOOYEWEERD, H. 1979. Roots of Western culture. Toronto: Wedge Publishing Foundation.

DUNSTAN, G.R. 1986. The moral status of the human embryo. London: King's Fund Publishing House.

DU TOIT, D.A. 1978. Die Christen en aborsie. Pretoria : N G Kerkboekhandel Transvaal.

EASTERN PROVINCE HERALD. 1990. Public views streaming in on abortion survey. Aug. 4, p. 5.

ENGLISH, J. 1981. Abortion and the concept of a person. (In Leiser, B.M., ed. Values in conflict. New York : MacMillan. p. 83/94.)

HäRING, B. 1982. Medical ethics. Middlegreen, Slough : St Paul Publications.

HEYNS, J.A. 1986 Teologiese etiek. Deel 2/1. Pretoria : N G Kerkboekhandel Transvaal.

IGLESIAS, T. 1984. In vitro fertilisation: the major issues. Joumal of Medical Ethics, I: 32-37.

KEMPERS, R.D., ed. 1986. Ethical considerations of the new reproductive technologios. Fertility and Sterility, 46:1 (Supplement 1) (The Ethics committee of the American Fertility Society).

KEMPERS, R.D., ed. 1988. Ethical considerations of the new reproductive technologies, Fertility and Sterility, 49:2 (Supplement 1).

KUHSE, H. 1982. An ethical approach to IVF and ET : What ethics is all about. (In Walters, W. \& Singer, P., eds. Test-tube babies. Melbourne : Oxford University Press. p. 22-35.)

KUHSE, H. \& SINGER, P. 1982. The moral status of the embryo: Two viewpoints. (In Walters, W. \& Singer, P., eds. Test-tube babies. Melbourne : Oxford University Press. p. 57-63.)

LEISER, B.M. 1981. Values in conflict - life, liberty and the rule of law. New York : MacMillan.

NOONAN, J.T. 1977 An almost absolute value in history. (In Mappes, T.A. \& Zembaty, J.S. Social Ethics. New York: McGraw-Hill. p. 12-17.) 
SCHUURMAN, E. 1989. Genetiese manipulasie - die wysgerig-etiese agtergronde. Potchefstroom : Instituut Reformatoriese Studies.

SCORER, G. \& WING, A. 1979. Decision making in medicine. London : Edward Arnold.

STRAUSS, D.F.M. 1990. Die mens en sy wêreld. Bloemfontein : Tekskor.

THE CAPE TIMES. 1990. Call for reform of abortion law in S.A. Jul. 7, p. 6

THE CAPE TIMES. 1991. Public doesn't want abortion law changed. April 10, p. 5.

THIELICKE, H. 1979. Theological ethics. Volume 3. Sex. Grand Rapids, Michigan : William B. Eerdmans.

TIME. 1989a. The battle over abortion. July 21, p. 38-40.

TIME. 1989b. A living human entity. Aug. 7, p. 24

TIME. 1989c. The globalization of the abortion debate. Aug. 21, p. 50-533.

TIME. 1989d. Enter stage right. Oct. 9, p. 66-67.

TOOLEY, M. 1981. Abortion and infanticide. (In Leiser, B. M., ed. Values in conflict. New York: MacMillan. p. 59-83.)

VISAGIE, PJ. 1990. The mission of the university and the critique of culture. Acta Academica, 22:1. Maart.

WALTERS, W.A.W. \& SINGER, P., eds. 1982. Test-tube babies. Medical Fellowship Melbourne : Oxford University Press.

WARREN, M. 1977. On the moral and legal status of abortion. (In Mappes, T.A. \& Zembaty, J.S. Social Ethics. New York: McGraw-Hill. p. 17-24.) 
